\title{
Soil Microbial-Community Alteration in Response to Heterotheca subaxillaris - an Invasive Alien Plant
}

\author{
Haggai Wasserstrom ${ }^{1} \&$ Yosef Steinberger ${ }^{1}$ \\ ${ }^{1}$ The Mina and Everard Goodman Faculty of Life Sciences, Ramat-Gan 5290002, Israel \\ Correspondence: Yosef Steinberger, The Mina \& Everard Goodman Faculty of Life Sciences, Bar-Ilan University, \\ Ramat-Gan 5290002, Israel. Tel: 972-3-5318571. Fax: 972-3-7384058. Email: Yosef.Steinberger@biu.ac.il
}

Received: April 25, 2018

Accepted: May 2, 2018

Online Published: May 11, 2018

doi:10.5539/enrr.v8n2p85

URL: https://doi.org/10.5539/enrr.v8n2p85

\begin{abstract}
Plant invasions have become one of the biggest threats to natural ecosystems across the globe during the last decade, and there is growing interest in their effect on the native flora and biota in invaded areas. However, little is known about their effect on soil microbial communities, especially non-fungal communities, in harsh environments such as a sand-dune ecosystem. The objective of this study, conducted in the northern Sharon sand-dune area of Israel, was to investigate the influence of the invasive alien plant Heterotheca subaxillaris on a sand-dune microbial community. Soil samples were collected under the canopies of the invasive plant, a native plant (Artemisia monosperma), and from bare areas at two sites, at different distances from the seashore going inland during the wet and dry seasons. MicroResp ${ }^{\mathrm{TM}}$ system methodology provided data on microbial biomass, basal respiration, and the community-level physiological profile (CLPP) at the community level, in addition to abiotic components, e.g., soil moisture, organic matter, conductivity, and $\mathrm{pH}$. The microbial community in the soil samples found under the canopy of $H$. subaxillaris was less active and exhibited significantly lower CLPP, microbial biomass, and basal respiration than in the A. monosperma (native plant) samples. Soil abiotic variables were strongly affected by seasonality, sites, and were related to plant cover and the ecophysiological adaptation of each one. This study emphasizes the threat to soil microbial communities induced by plant invasion, especially in unique and harsh sand-dune ecosystems. This threat might also affect other organisms living in this fragile environment.
\end{abstract}

Keywords: Biomass; functional diversity; invasive plant species; microbial community; sand dune habitat

\section{Introduction}

Invasive alien plants have become a major threat to global biodiversity on many trophic levels (Levine et al., 2003), and, therefore, have become of great interest in recent years (Callaway \& Maron, 2006). Invasive vegetation can affect both plant and animal diversity (Vilà et al., 2011), having negative effects on the fauna and functional ecology of ecosystems (Williams \& Karl, 2002; Traveset \& Richardson, 2006; van der Putten et al., 2007a). These invasive species affect native plants in multiple ways, e.g., competition for nutrients and water, prevention of sunlight, and creation of allelopathic effects (Cronk \& Fuller, 2001; Levine et al., 2003; Chen et al., 2009; Bennett et al., 2011; Dufour-Dror, 2012). Moreover, they also may affect below-ground biota (Kourtev et al., 2002; Meisner et al., 2014). According to Ehrenfeld (2003), plant invasion greatly affects ecosystem functioning and processes that may be facilitated through changes in nutrient cycles (Liao et al., 2008) or soil properties, e.g., soil structure or ground-water hydrology (Hicks, 2004; Hill et al., 2005; Weidenhamer \& Callaway, 2010).

Many studies have emphasized the importance of environmental factors (Paradelo and Barral, 2009; Ehrlich et al., 2015) and changes in plant cover to soil organisms in terrestrial ecosystems (Grayston et al., 2001; Wolfe and Klironomos, 2005; Berg \& Steinberger, 2008; Wasserstrom et al., 2016). Soil microorganisms are vital components of any terrestrial ecosystem because of their role in decomposition and nutrient cycling, thereby affecting primary productivity and soil nutrient content. Moreover, they facilitate soil particle aggregation, a keystone in the formation and stabilization of soil (Forster \& Nicolson, 1981). Plant cover has a tremendous direct effect on soil and its microbial communities (Kardol et al., 2007; Berg \& Smalla, 2009) by providing organic matter and nutrients (Aguilera et al., 1999; Wardle et al., 2004) and releasing root exudates (Coleman et al., 2000; Bais et al., 2006). A change in the plant community, such as occurs with plant invasion, will trigger a cascade of biochemical processes that can eventually change the soil biota (Kourtev et al., 2002; Ehrenfeld, 2003; Belnap et 
al., 2005; Wolfe and Klironomos, 2005; van der Putten et al., 2007a). Vivanco et al. (2004) showed that there are alien plants that not only release allelochemicals, but also inhibit mutualistic fungi associated with the roots of native plants (Mummey \& Rillig, 2006). The studies conducted by Gillespie and Allen (2006) and Batten et al. (2008) also demonstrated that changes in soil-community composition associated with invasive plants had a negative influence on the performance of neighboring native plants.

During the past decade, the role that soil biota plays in controlling the success of the invasive plants has been shown in several studies (Klironomos, 2002; Reinhart \& Callaway, 2006; Pringle et al., 2009; Inderjit \& van der Putten, 2010). Soil organisms were found to be the major component of the biodiversity of any terrestrial ecosystem (Vandenkoornhuyse et al., 2002), and had a tremendous effect on plant communities and performance (van der Putten, 2009; Philippot et al., 2013). Several studies have shown that the net effect of soil biota has a positive or less negative effect on invasive plants relative to the native plants, which provides them an advantage in their surroundings (Callaway et al., 2004; Agrawal et al., 2005; van der Putten et al., 2007b; Engelkes et al., 2008; Kulmatiski et al., 2008; Gundale et al., 2014; Maron et al., 2014). Although the significance of soil biota in plant invasions was elucidated more than a decade ago, there is still much that is unknown about their interactions (Klironomos, 2002; Yang et al., 2013). Many of the studies conducted in this field have been done in relation to soil nematodes and fungi (van der Putten et al., 2007b ; Rodríguez-Echeverría et al., 2009; Day et al., 2015), but there is a lack of knowledge concerning the different components of the soil microbiota. Therefore, expanding our knowledge of these effects on the organisms living beneath our feet, especially in harsh environments such as dune ecosystems, is crucial and much needed.

In their study, Foster and Tilman (2000) showed that sand-dune ecosystems are a dynamic habitat and generally exhibit the successional development of plant communities. They represent the earliest stages in soil development (Jones et al., 2008) that change with the alterations in plant cover. These ecosystems are unstable due to sand movement and fast-draining soils that are low in nutrients and that limit the organisms living below- and above-ground in such habitats (Breckle et al., 2008; Kutiel et al., 2016; Levin et al., 2008). A soil microbial community is an important bioindicator of the quality of the soil in particular, and the state of the terrestrial ecosystem in general (Anderson, 2003; Schloter et al., 2003; Wagg et al., 2014). It is known to be one of the communities most sensitive to external changes, reacting instantaneously to biotic, as well as to abiotic, triggers and that greatly contributes to the maturation and stabilization of sand dunes (Nicolson, 1960; Maun, 2009). Hence, the soil microbial community can serve as a good bioindicator for studying the effect of an invasive plant on the soil in a sand-dune ecosystem. In recent years, there have been many studies on sand-dune soil biotic interactions with native and invasive plants, but most those studies were related to temperate-climate ecosystems (van der Stoel et al., 2002; Rodríguez-Echeverría et al., 2009; Sikes et al., 2012).

The Israeli Mediterranean sand dunes are exposed to high radiation levels and high temperatures during summer. This combination creates an arid environment within a Mediterranean climate, even though there is enough precipitation in these areas. As a result, the plant communities consist of psammophilic species as well as by desert species (Kutiel, 2001). The unique conditions and sparse vegetation cover in the active sand dunes make them sensitive to changes caused by external forces, such as invasive species. Heterotheca subaxillaris (Asteraceae) is a common annual or biennial plant that grows in sandy areas throughout the USA, and was introduced in Israel in 1975 to stabilize mobile sand dunes (Dafni \& Heller, 1980). Within a few years, it became an invasive species, spreading out to many sandy areas and roadsides on the coastal plain, where it was found to be perennial. Its ability to grow in poor environments and at several reproduction strategies (Baskin \& Baskin, 1976; Awang \& Monaco, 1978; Lonard et al., 2011) has allowed H. subaxillaris to invade and conquer new areas (Ben-Shahar, 2010; Dufour-Dror, 2012). Moreover, the plant leaves are covered with glandular trichomes, which secrete volatile chemical compounds found to be phytotoxic (Morimoto et al., 2009). There is also evidence that $H$. subaxillaris excludes native species such as Artemisia monosperma (Asteraceae), a dominant and important plant in the sand-dune plant communities in Israel (Dufour-Dror, 2012) that is also known to have allelopathic effects (Al-Watban \& Salama, 2012). Furthermore, the study of Fitoussi et al. (2016) showed a decrease in a soil nematode community in the soil samples collected under the canopy of $H$. subaxillaris compared with the samples collected under the native plant.

As soil biota plays a key role in maintaining local biodiversity (De Deyn et al., 2003; Kardol et al., 2013) and significantly affects all trophic levels (Piśkiewicz et al., 2007), understanding how it is affected by this invasion, especially in harsh and low-nutrient ecosystems, is of great importance. The purpose of the present study was to evaluate the effect of invasive sand-stabilizing plant presence on a soil microbial community collected under the canopy of $H$. subaxillaris as compared with that collected under natural vegetation cover, while both species are known to have allelopathic features. In order to be able to evaluate the invasive-plant effect in an arid environment 
with a Mediterranean climate, we assessed soil microbial-community functionality and activities in the samples obtained under the canopy of the invasive plant $H$. subaxillaris and the native plant $A$. monosperma, with the bare, open areas serving as a control. The soil samples were collected at two sites of different proximity to the sea during the dry and wet seasons in a Mediterranean sand-dune ecosystem.

We hypothesized that microbial-community functionality and activities, expressed as biomass, basal respiration, functional diversity, and physiological profile, will be lower in the presence of the invasive plant in comparison with the natural-soil microbial community under the canopy of the native plant, while they will increase in comparison with the community of the bare areas. These changes will be more significant at the site near the seashore, and the environmental conditions are expected to be harsher compared with those at a more inland site (McLachlan \& Brown, 2006). Moreover, sampling in different seasons will strongly elucidate the changes in both the biotic and abiotic constituents and the relationship between the two.

\section{Materials and Methods}

\subsection{Study Site}

In the present study, two sites were chosen in the northern Sharon Plains of Israel: a western site $\left(32^{\circ} 28^{\prime} \mathrm{N}, 34^{\circ} 53^{\prime} \mathrm{E}\right)$ and an eastern site $\left(32^{\circ} 29^{\prime} \mathrm{N}, 34^{\circ} 55^{\prime} \mathrm{E}\right)$, located 500 and $4100 \mathrm{~m}$ from the Mediterranean Sea shore, respectively. These two sites consist of sand dunes with similar topography plant cover. The sandy dunes are semi-stabilized dunes, with vegetation consisting of a matrix of shrubs with open sandy patches between them. The most abundant shrubs in this area are A. monosperma, Retama raetam, and $H$. subaxillaris, which cover less than $15 \%$ of the study sites. The color of the sand varies from yellowish (west) to yellow-reddish (east), according to the amount of organic matter, iron, and fine-grained deposits (Danin \& Yaalon, 1982). The climate is subhumid Mediterranean, with a multiannual mean rainfall of $580 \mathrm{~mm}$, falling mainly during winter-early spring (October to March), with maximum rainfall in December. The mean minimum daily temperature reaches $10.5^{\circ} \mathrm{C}$ in January, while the mean maximum daily temperature reaches $28.5^{\circ} \mathrm{C}$ in August.

\subsection{Soil Sampling}

Soil samples were collected from the 0-10-cm layer (without litter) at each site, at the three habitats: under the canopy of $A$. monosperma shrubs, under the canopy of $H$. subaxillaris shrubs, and at the bare, open spaces between the shrubs $(\mathrm{n}=4)$. Each replicate soil sample represented a composed pool that was the result of a five-point (four corners and the middle) collection from a quadrat $(1 \mathrm{~m} \times 1 \mathrm{~m})$. Each soil sample $(\mathrm{n}=4)$ was collected beneath the canopy of an individual shrub that was at least $8 \mathrm{~m}$ away from the closest shrubs of other species and $10 \mathrm{~m}$ away from shrubs of the same species. The soil samples collected were placed in a polyethylene bag, gently mixed, and transported to the laboratory in an insulated container. The four replicates (quadrats) were collected at least $30 \mathrm{~m}$ from each other. The soil samples were collected on January 6 (representing the wet season) and on August 30 (representing the dry season), 2015. A total of 48 soil samples were collected during the study period. Prior to physicochemical and biological analyses, stones, roots, and other organic debris were removed from the samples by using a $2 \mathrm{~mm}$ sieve, and the samples were then stored at $4^{\circ} \mathrm{C}$.

\subsection{Soil Analysis}

\subsubsection{Soil Properties}

Subsamples from each replicate were analyzed to determine the following soil properties: Soil moisture was determined gravimetrically by drying the soil samples at $105^{\circ} \mathrm{C}$ for $48 \mathrm{~h}$ and measuring the mass loss. Organic matter was detected by oxidation with dichromate in the presence of $\mathrm{H}_{2} \mathrm{SO}_{4}$ (Rowell, 1994). Salinity was measured by measuring electrical conductivity in a soil-water suspension (soil:double distilled water $=1: 10$ ). $\mathrm{pH}$ was determined using a combined $\mathrm{pH}$ electrode in a soil-water suspension (soil:tap water $=1: 2$ ).

\subsection{Biotic Parameters}

Soil microbial biomass (measured by glucose-induced respiration rates) (Anderson \& Domsch, 1978) and basal respiration (with no additional external substrate) were determined for each of the soil samples using the MicroResp ${ }^{\mathrm{TM}}$ method (Campbell et al., 2003). Microbial functional diversity and community-level physiological profile (CLPP) in the soil were also measured by this system. Colorimetric gel detector plates were filled with $1 \%$ Noble agar $\left(150 \mu \mathrm{l} \mathrm{well}^{-1}\right)$ containing a $\mathrm{pH}$ indicator dye, cresol red $\left(12.5 \mu \mathrm{g} \mathrm{g} \mathrm{g}^{-1} \mathrm{wt} / \mathrm{wt}\right), 150 \mathrm{mM}$ potassium chloride, and $2.5 \mathrm{mM}$ sodium bicarbonate. Eight different carbon sources, including amino acids, carbohydrates, bases, and acids (including carboxylic and aromatic acids) were selected from the fifteen suggested by Campbell et al. (2003), similar to Creamer et al. (2016). These were $\gamma$-amino butyric acid (GABA), L-lysine, n-acetyl-glucosamine (NAGA), 3,4-dihydroxybenzoic acid, D-galactose, D-glucose, citric acid, and L-malic acid. Amounts of $20 \mathrm{~g}$ of soil from each soil sample were then incubated for $48 \mathrm{~h}$ in the dark at $25^{\circ} \mathrm{C}$ and at $40 \%$ of their 
water-holding capacity. Twenty-five $\mu \mathrm{l}$ of the eight carbon sources and distilled water (blank) were respectively dispensed into deep well plates, and equal volumes of distilled water were added to other deep wells in order to determine soil basal respiration, while the glucose was used to determine microbial biomass. The incubated soil samples were added to the substrate plates using the Campbell method (Campbell et al., 2003), and the plates were left open for a period of $45 \mathrm{~min}$ to allow for the release of any carbonates present in the soils (Creamer et al., 2016). The respired $\mathrm{CO}_{2}$ was absorbed by the gel detection plates and measured using a spectrophotometer at $590 \mathrm{~nm}$. The plates were read twice: just before and $6 \mathrm{~h}$ after being placed on the deep well plates containing the soil samples and carbon sources. During this period, the plates were incubated in the dark at $25^{\circ} \mathrm{C}$. Respiration rates were calculated from adsorption data, minus the well containing only water with the soil sample (blank). The results for each well were calculated based on the initial colorimetric value. Microbial functional diversity was evaluated using the Shannon-Weaver index $\left(H^{\prime}\right): H^{\prime}=-\Sigma p_{\mathrm{i}}\left(\ln p_{\mathrm{i}}\right)$, where $p_{\mathrm{i}}$ is the ratio of the activity of a particular substrate and the sum of activities of all substrates (Zak et al., 1994).

\subsection{Statistical Analysis}

All data were subjected to statistical analysis of variance using the SAS model (general linear model). Duncan's multiple range tests were used to establish the significance of differences between separate means [general linear model (GLM)]. Differences obtained at levels of $p<0.05$ were considered significant. These data were also subjected to redundancy discriminant analysis (RDA) using CANOCO (Version 4.5; Microcomputer Power Inc., Ithaca, NY), for which a Monte Carlo reduced model test with 499 unrestricted permutations was applied to evaluate the statistical significance of the environmental factors to the obtained results and the proportion of variation (ter Braak, 1995). RDA analysis produced graphic illustrations, with arrows relating the environmental factors to their corresponding measured parameters. Arrows pointing in similar directions indicate a positive correlation, while arrows pointing in opposite directions indicate a negative one. The longer the arrow is, the greater the significance of the relationship.

\section{Results}

The soil properties, i.e., soil moisture, organic matter, salinity, and $\mathrm{pH}$, of the different habitats during two seasons, are summarized in Table 1 . Soil moisture $(n=48)$ was only found to be strongly affected by season (Table 2 ). During both seasons, the eastern site was consistently found to have higher soil moisture at all three habitats compared with their parallels at the western site. However, no significant differences were observed between the different habitats at the same site and season. Soil organic matter was found to be significantly affected by season, site, habitat, and the interplay between season and site and between season and habitat (Table 2). The soil samples collected throughout the study period contained a low level of organic matter, ranging from 0.012 to $0.162 \%$. Moreover, soil organic matter was significantly lower $(p<0.05)$ in the bare-area samples compared with those taken under the canopies of the plants, except at the eastern site during the dry season. During the wet season, a higher level of soil organic matter was found under the canopy of $H$. subaxillaris compared with the native plant $A$. monosperma, while this trend was reversed during the dry season. During the wet season, organic matter collected at the western site was at least double the organic matter collected at the eastern site.

Table 1. Changes in the mean values (standard error in parentheses, $\mathrm{n}=4$ ) of soil moisture, organic matter, salinity, and $\mathrm{pH}$ in soil samples collected at three habitats (under the canopies of A. monosperma and H. subaxillaris, and in the bare areas) at the two sites (west and east) during the wet and dry seasons. Values with the same letter in the same season and site are not significantly different (Duncan's test, $p>0.05$ )

\begin{tabular}{|c|c|c|c|c|c|c|c|c|}
\hline & \multicolumn{8}{|c|}{ Wet } \\
\hline & \multicolumn{4}{|c|}{ West } & \multicolumn{4}{|c|}{ Eeast } \\
\hline & Soil moisture (\%) & Organic matter $(\%$ & Salinity $(\mathrm{mS} / \mathrm{cm})$ & pH & Soil moisture (\%) & Organic matter (\%) & Salinity $(\mathrm{mS} / \mathrm{cm})$ & pH \\
\hline Bare areas & $2.24(0.23)^{\mathrm{a}}$ & $0.061(0.052)^{\mathrm{b}}$ & $2.25(0.14)^{\mathrm{a}}$ & $8.03(0.05)^{\mathrm{a}}$ & $2.33(0.06)^{\mathrm{a}}$ & $0.012(0.002)^{\mathrm{b}}$ & $2.20(0.22)^{\mathrm{a}}$ & $7.55(0.27)$ \\
\hline A. nonosperma & $2.60(0.39)^{\mathrm{a}}$ & $0.154(0.073)^{\mathrm{a}}$ & $2.20(0.23)^{\mathrm{a}}$ & $8.00(0.06)^{\mathrm{a}}$ & $2.73(0.39)^{\mathrm{a}}$ & $0.039(0.004)^{\mathrm{ab}}$ & $2.35(0.18)^{\mathrm{a}}$ & $7.36(0.11)^{t}$ \\
\hline \multirow[t]{4}{*}{ H. subaxillaris } & $2.40(0.44)^{\mathrm{a}}$ & $0.162(0.031)^{\mathrm{a}}$ & $2.13(0.19)^{\mathrm{a}}$ & $8.02(0.02)^{\mathrm{a}}$ & $2.48(1.34)^{\mathrm{a}}$ & $0.081(0.047)^{\mathrm{a}}$ & $1.86(0.07)^{\mathrm{b}}$ & $8.00(0.05)$ \\
\hline & \multicolumn{8}{|c|}{ Dry } \\
\hline & \multicolumn{4}{|c|}{ West } & \multicolumn{4}{|c|}{ Eeast } \\
\hline & Soil moisture $(\%)$ & Organic matter $(\%$ & Salinity $(\mathrm{mS} / \mathrm{cm})$ & pH & Soil moisture (\%) & Organic matter (\%) & Salinity (mS/cm) & pH \\
\hline Bare areas & $0.03(0.06)^{\mathrm{a}}$ & $0.031(0.01)^{\mathrm{b}}$ & $2.66(0.29)^{\mathrm{b}}$ & $7.87(0.03)^{\mathrm{a}}$ & $0.28(0.16)^{\mathrm{a}}$ & $0.064(0.075)^{\mathrm{a}}$ & $2.46(0.23)^{\mathrm{b}}$ & $7.82(0.03)$ \\
\hline A. nonosperma & $0.09(0.12)^{\mathrm{a}}$ & $0.081(0.034)^{\mathrm{a}}$ & $3.19(0.25)^{\mathrm{a}}$ & $7.81(0.03)^{\mathrm{a}}$ & $0.09(0.12)^{\mathrm{a}}$ & $0.061(0.012)^{\mathrm{a}}$ & $2.85(0.48)^{\mathrm{a}}$ & $7.84(0.05)$ \\
\hline H. subaxillaris & $0.16(0.06)^{\mathrm{a}}$ & $0.052(0.02)^{\mathrm{ab}}$ & $2.19(0.09)^{\mathrm{c}}$ & $7.82(0.04)^{\mathrm{a}}$ & $0.28(0.12)^{\mathrm{a}}$ & $0.029(0.008)^{\mathrm{a}}$ & $2.83(0.26)^{\mathrm{a}}$ & $7.85(0.05)$ \\
\hline
\end{tabular}


Soil salinity was found to be higher in the dry season sampling period in all habitats compared with the corresponding values in the wet season, except for A. monosperma at the eastern site (Table 1). Soil salinity was significantly affected by season, site, the combination of season and site, the combination of season and habitat, and the combination of season, site, and habitat (Table 2). On the average, soil salinity was found to be lower $(p<0.05)$ under $H$. subaxillaris than under A. monosperma. However, during the dry season, no differences were found at the eastern sampling site. The $\mathrm{pH}$ was slightly alkaline in both seasons, with a slightly higher value in the wet season at the western site compared with the eastern site. Overall, the $\mathrm{pH}$ values ranged from 7.4 to 8.03 , and were not significantly affected by site and habitat and by all the permutations of the three parameters. However, there were no significant differences between the habitats except during the wet season at the eastern site, where the $\mathrm{pH}$ under the canopy of $H$. subaxillaris showed a significantly higher value $(\mathrm{p}<0.05)$ compared with the control and $A$. monosperma samples.

Table 2. General linear model (GLM) results of abiotic and biotic soil parameters with seasons (wet and dry), sites (west and east), and habitats (under the canopies of $A$. monosperma and H. subaxillaris, and in the bare areas)

\begin{tabular}{|c|c|c|c|c|c|c|c|c|c|c|c|c|c|c|}
\hline & \multicolumn{2}{|c|}{ Season } & \multicolumn{2}{|c|}{ Site } & \multicolumn{2}{|c|}{ Season $\times$ Site } & \multicolumn{2}{|c|}{ Habitat } & \multicolumn{2}{|c|}{ Season $\times$ Habitat } & \multicolumn{2}{|c|}{ Site $\times$ Habitat } & \multicolumn{2}{|c|}{ Season $\times$ Site $\times$ Habitat } \\
\hline & $F$-test & $p$-value & F-test & $p$-value & F-test & $p$-value & F-test & $p$-value & F-test & p-value & F-test & $p$-value & F-test & $p$-value \\
\hline Soil moisture & 314.26 & $<0.0001$ & 1.09 & NS & 0.07 & NS & 0.61 & NS & 0.86 & NS & 0.03 & NS & 0.06 & NS \\
\hline Organic matter & 7.73 & 0.0086 & 15.66 & 0.0003 & 9.89 & 0.0033 & 5.37 & 0.0091 & 4.84 & 0.0138 & 2.82 & NS & 0.26 & NS \\
\hline Salinity & 58.18 & $<0.0001$ & 11.01 & 0.0021 & 6.25 & 0.0171 & 0.6 & NS & 5.1 & 0.0112 & 1.94 & NS & 8.83 & 0.0008 \\
\hline pH & 0.11 & NS & 53.01 & $<0.0001$ & 47.29 & $<0.0001$ & 15.19 & $<0.0001$ & 11.54 & 0.0001 & 12.26 & $<0.0001$ & 11.41 & 0.0001 \\
\hline Basal respiration & 29.64 & $<0.0001$ & 0.11 & NS & 24.92 & $<0.0001$ & 18.74 & $<0.0001$ & 8.3 & 0.0011 & 11.85 & 0.0001 & 4.57 & 0.017 \\
\hline Microbial biomass & 0 & NS & 25.17 & $<0.0001$ & 19.56 & $<0.0001$ & 38.55 & $<0.0001$ & 3.61 & 0.0372 & 17.27 & $<0.0001$ & 0.17 & NS \\
\hline GABA & 12.35 & 0.0016 & 18.41 & 0.0002 & 6.5 & 0.0168 & 23.04 & $<0.0001$ & 16.01 & $<0.0001$ & 2.71 & NS & 2.19 & NS \\
\hline Lysine & 10.5 & 0.0028 & 11.02 & 0.0023 & 15.95 & 0.0004 & 8.17 & 0.0014 & 9.55 & 0.0006 & 5.22 & 0.0109 & 4.1 & 0.0259 \\
\hline NAGA & 3.03 & NS & 13.69 & 0.0008 & 0.58 & NS & 15.23 & $<0.0001$ & 0.7 & NS & 3.79 & 0.0332 & 1.07 & NS \\
\hline Benzo & 2.31 & NS & 4.7 & 0.0378 & 1.05 & NS & 58.15 & $<0.0001$ & 4.41 & 0.0203 & 15.37 & $<0.0001$ & 0.61 & NS \\
\hline Galactose & 0.73 & NS & 22.89 & $<0.0001$ & 8.65 & 0.0066 & 28.17 & $<0.0001$ & 1.65 & NS & 25.72 & $<0.0001$ & 8.17 & 0.0017 \\
\hline Citric acid & 17.38 & 0.0002 & 2.18 & NS & 8.58 & 0.0061 & 17.69 & $<0.0001$ & 3.11 & NS & 15.26 & $<0.0001$ & 2.24 & NS \\
\hline Malic acid & 119.07 & $<0.0001$ & 1.69 & NS & 3.71 & NS & 71 & $<0.0001$ & 1.99 & NS & 26.8 & $<0.0001$ & 3.38 & 0.0467 \\
\hline$H^{\prime}$ & 3.53 & NS & 15.94 & 0.0003 & 2.11 & NS & 15.26 & $<0.0001$ & 1.58 & NS & 12.23 & $<0.0001$ & 2.3 & NS \\
\hline
\end{tabular}

GABA - $\gamma$-amino butyric acid; NAGA - n-acetyl-glucosamine; Benzo - 3,4-dihydroxybenzoic acid. The bold highlights the significant changes.
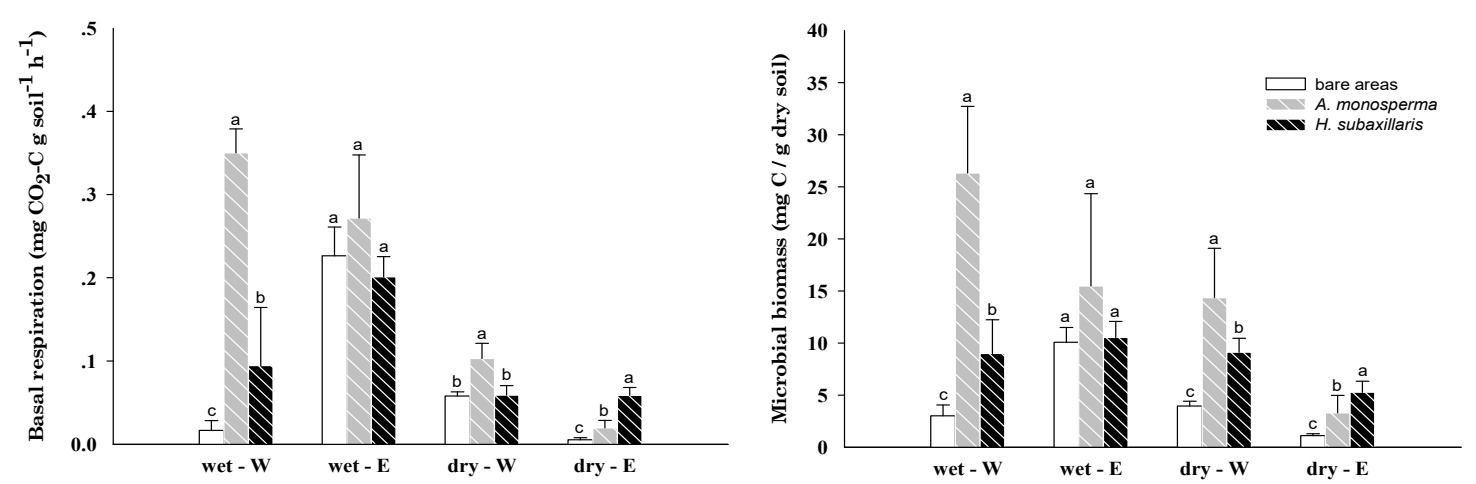

Figure 1. Changes in the mean values of basal respiration levels and microbial biomass in soil samples collected from three habitats, i.e., under the canopies of A. monosperma and $\mathrm{H}$. subaxillaris, and in the bare areas, at two sites ('W' - west, 'E' - east) during the wet and dry seasons. The letters represent statistically significant differences (Duncan's test, $\mathrm{p}<0.05$ ) between the three habitats in the same season and site 

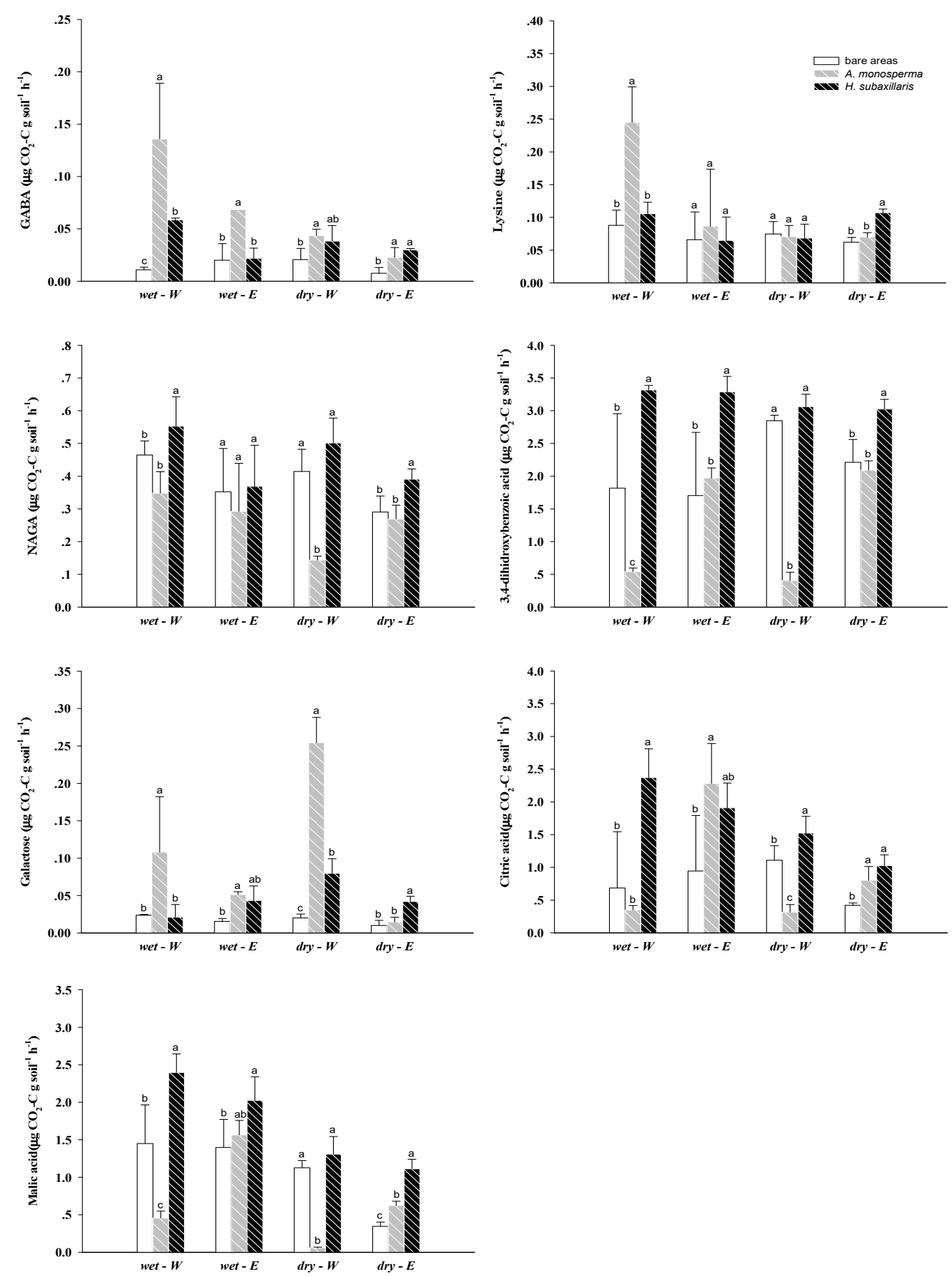

Figure 2. Changes in the mean values of the different carbon substrate utilization rates in soil samples collected from the three habitats, i.e., under the canopies of A. monosperma and H. subaxillaris, and in the bare areas, at the two sites ('W' - west, 'E' - east) during the wet and dry seasons. The letters represent statistically significant differences (Duncan's test, $p<0.05$ ) between the three habitats in the same season and site

The spatial fluctuations in basal respiration levels of the sandy soil collected during the study period exhibited different trends throughout the study period (Figure 1). The basal respiration levels were strongly affected by season, habitat, the interplay (season $\times$ habitat) between them, as well as by the sampling site (Table 2). Basal respiration was found to be higher in samples collected under the canopy of A. monosperma at most sample sites compared with samples collected under the canopy of $H$. subaxillaris and samples from the bare, open spaces. 
Overall, the highest values were obtained during the wet season compared with their corresponding samples during the dry season. Microbial biomass (mean) values were found to be significantly affected by site, habitat, and the combination of the two. In the wet, winter sampling season, microbial biomass was found to be significantly higher $(p<0.001)$ in all the eastern-site habitats compared with their corresponding habitats in the dry season. Overall, microbial biomass was found to be significantly $(\mathrm{p}<0.05)$ higher in the samples collected under the canopy of A. monosperma, relative to H. subaxillaris, and in the samples from the bare, open spaces.

The outcomes of statistical tests describing the influence of environmental parameters on the substrate utilization of different carbons are presented in Table 2. The habitat was found to have a significant effect on the utilization of all the carbon substrates, while season affected only GABA, lysine, citric acid, and malic acid. The interplay of site and habitat was found to affect the utilization of all substrates except GABA. Lysine utilization was found to be affected by sampling site, seasonality, and habitat, as well as by the combination of these parameters. NAGA utilization was found to be affected by site, habitat, and the combination of the two.

The substrate utilization rates of soil samples collected under the canopy of the native plant $A$. monosperma were significantly different from those of soil samples collected under the canopy of $H$. subaxillaris and from the open spaces for most substrates and sites (Figure 2). Samples obtained under the canopy of H. subaxillaris were found to be significantly different in comparison with the open-space samples in the utilization of all substrates except lysine. The utilization rates of GABA, lysine, and galactose were found to be highest in the samples collected under canopy of $A$. monosperma at most sites, whereas NAGA, 3,4-dihydroxybenzoic acid, citric acid, and malic acid were highest in samples collected under the canopy of $H$. subaxillaris. No significant differences in the utilization of NAGA and 3,4-dihydroxybenzoic acid were found between the three habitats.

Table 3. Redundancy analysis (RDA) of the utilization rates of the different substrates for quantifying the conditional effects of the measured abiotic variables on the substrate-utilization profile of the microbial community using forward selection with the Monte Carlo permutation test

\begin{tabular}{|c|c|c|}
\hline Axis & 1 & 2 \\
\hline Eigenvalues & 0.146 & 0.093 \\
\hline \multicolumn{3}{|l|}{ Cumulative percentage variance: } \\
\hline of species data & 14.6 & 23.8 \\
\hline of species-environment relation & 60.4 & 98.9 \\
\hline Summary of Monte Carlo test: & & For all axes: \\
\hline$F$-ratio & 7.32 & 3.41 \\
\hline$p$-value & 0.04 & 0.006 \\
\hline Species-environment correlations & 0.525 & 0.467 \\
\hline \multicolumn{3}{|l|}{ Correlations (r): } \\
\hline $\begin{array}{l}\text { Soil } \\
\text { moisture }\end{array}$ & $-0.428 *$ & -0.816 \\
\hline $\begin{array}{l}\text { Organic } \\
\text { matter }\end{array}$ & 0.122 & 0.232 \\
\hline salinity & $0.404 *$ & 0.769 \\
\hline $\mathrm{pH}$ & 0.15 & 0.285 \\
\hline
\end{tabular}

Values are for Axes 1 and 2 plotted in the RDA figure. The highest canonical correlations are highlighted by an asterisk that indicates significance $(p<0.05)$.

Redundancy analysis (RDA) was conducted in order to describe the multiple substrate-induced respiration of the carbon-substrate utilization. Analysis showed that the four soil physicochemical parameters [soil moisture, organic carbon (OC), salinity, and $\mathrm{pH}]$ together accounted for $24.1 \%$ of the total variation in the data, with axes 1 and 2 accounting for $14.6 \%$ and $9.3 \%$ of the total variation, respectively (Table 3 ). The species - environment relationship for axes 1 and 2 for environmental variables accounted for $98.9 \%$ of the total variance, indicating that together, these axes accounted for most of the variance in substrate utilization that can be attributed to environmental factors. Monte-Carlo analysis with 499 permutations revealed that both the first axis and all axes combined (Table 3) accounted for a significant amount of the variation within the data. The response of the substrates to the various soil properties in the different habitats during the study period is described in Figure 3. The effect of salinity was strongly related to the dry season trend, which changed in the wet season. The increase in SM during the wet season increased the substrate utilization of NAGA, malic acid, and citric acid. In addition, 
microbial biomass was found to be strongly affected by OC, while basal respiration was found to be significantly affected by the change in soil moisture.

The highest microbial functional diversity values $\left(H^{\prime}\right)$ were found in the samples taken at the western site under the canopy of $A$. monosperma, but no differences between habitats were observed at the eastern site (Table 2, Figure 4) The $H$. subaxillaris samples showed no significant changes in their $H^{\prime}$ values, and we found similar diversity in soil samples collected under its canopy as compared with the samples collected in the bare area.

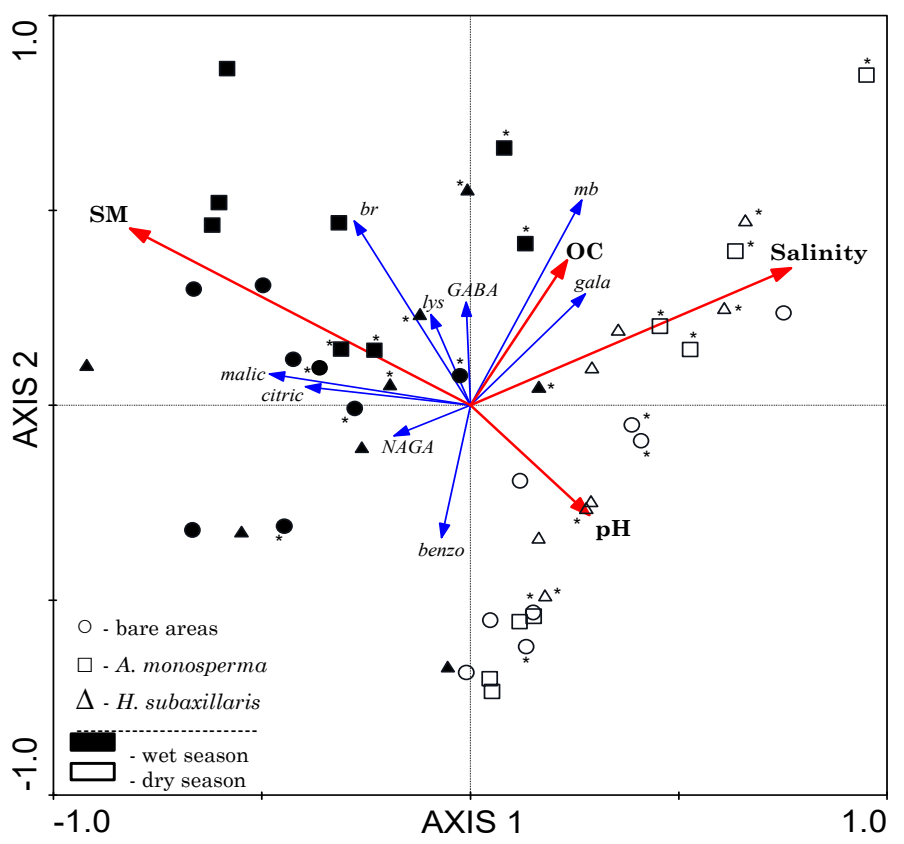

Figure 3. Redundancy analysis (RDA) showing the relationship between basal respiration, microbial biomass, the different substrate-utilization rates, and environmental variables, at the different sites (west and east; an asterisk denotes samples from the western site) and habitats (under the canopies of A. monosperma and H. subaxillaris, and in the bare areas) during two seasons (soil samples are represented by symbols). SM - soil moisture; OM - organic matter; br - basal respiration; mb - microbial biomass; GABA - $\gamma$-amino butyric acid; lys - lysine; NAGA n-acetyl-glucosamine; benzo - 3,4-dihidroxybenzoic acid; gala - galactose; citric - citric acid; malic - malic acid

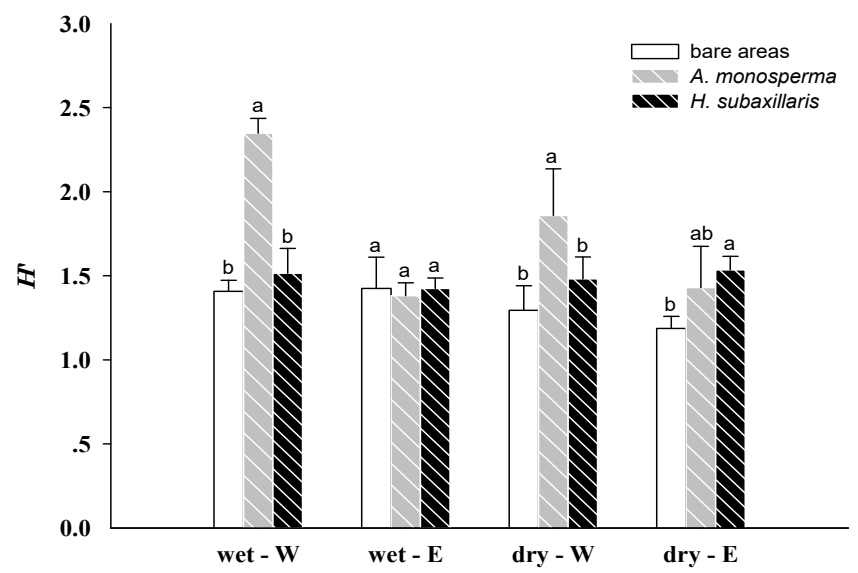

Figure 4. Changes in the mean values of the Shannon-Weaver index $\left(H^{\prime}\right)$ in soil samples collected from the three habitats (under the canopies of A. monosperma and H. subaxillaris, and in the bare areas) at the two sites ('W'west, ' $E$ ' - east) during the wet and dry seasons. The letters represent statistically significant differences (Duncan's test, $p<0.05$ ) between the three habitats in the same season and site 


\section{Discussion}

Invasive species in general, and invasive alien plants in particular, have become one of the biggest threats to natural environments across the globe (Foxcroft et al., 2013). Invasive plants have been shown to have a great impact on soil, and on above- and below-ground biota (Reinhart \& Callaway, 2006; Kivlin \& Hawkes, 2011; Morriën et al., 2012; Day et al., 2015). Even so, little is known about the interactions of invasive alien plants and soil biota in sand-dune ecosystems (van der Stoel et al., 2002; Rodríguez-Echeverría et al., 2009).

Our results obtained in the present study on microbial biomass and basal respiration rates support the above-mentioned findings showing that invasive plants specifically change habitats and ecosystems in a broad sense. In general, we found higher respiration rates and microbial biomass in soil samples collected under the canopy of the native plant $A$. monosperma, while under the invasive plant $H$. subaxillaris, both were lower and even similar to the bare areas in the case of basal respiration. This trend is similar to the negative effect of $H$. subaxillaris on a soil nematode community, as found by Fitoussi et al. (2016). The highest respiration and biomass values were obtained during the wet season, which can be attributed to the combination of higher soil-water availability and lower salinity during this season in the study area. During this season, the basal respiration rates and microbial biomass in the samples collected under the canopy of A. monosperma were significantly higher $(p<0.05)$ at both sites compared with the dry season. This trend was not observed with $H$. subaxillaris and the bare areas, and only the eastern site exhibited significantly higher basal respiration and microbial biomass during the wet season compared with the dry one. These changes might be a result of the differences in the morphology of these two plants and its effect on wind velocity, and therefore, on sand movement. In sand dunes, wind can affect the distribution of soil biota, e.g., fungi, nematodes, and microarthropods (de Rooij-van der Goes et al., 1997; Wasserstrom and Steinberger, 2016). During the wet winter, there are strong winds in the shore areas at the Israeli Mediterranean coast that get weaker as they move east and inland; therefore, sand movement also decreases from seashore towards land (Goldsmith et al., 1990). While the canopy of A. monosperma is wider and closer to the surface, thus covering and protecting a wider area of the soil, the canopy of $H$. subaxillaris is thinner and not close to the surface, so there is less protection of the soil surface from the winds, and more sand transport. This results in a harsher environment at the western site during the wet winter, which probably does not allow the usage of the higher soil moisture by the soil microflora in the samples collected under the canopy of $H$. subaxillaris, which is similar to the bare areas. This can also be supported by the redundancy analysis results, which indicate that the four environmental variables measured by us were responsible only for part of the variation in the obtained data, and that some other factors might have contributed to the unexplained variation. During the dry season, significantly higher respiration rates and microbial biomass $(p<0.05)$ were found at the western site under both plants (with the exception of basal respiration in samples collected under the canopy of $H$. subaxillaris), probably due to the higher organic matter in these samples.

Although there were significant differences in most substrate utilization rates, there was no clear trend for the three habitats. In some, higher rates were found in the samples collected under the canopy of A. monosperma, while in others, the higher rates were found in the samples collected under the canopy of H. subaxillaris, but overall, in most samples, utilization rates in samples collected under the canopy of $H$. subaxillaris were significantly different from both the samples collected under the canopy of $A$. monosperma and the bare-area samples. Moreover, the utilization rates of all substrates except lysine were significantly higher in the

H. subaxillaris samples compared with the bare-area samples in most seasons and sites, a phenomenon that was not so strong in the A. monosperma samples. This can be a result of the specific allelochemicals that

A. monosperma secretes (Al-Watban and Salama, 2012), which might influence the soil microbial community, as found in different ecosystems with many plant species (Kong et al., 2008; Cipollini et al., 2012; Zhou et al., 2013; Souza-Alonso et al., 2015; Niro et al., 2016) in order to prevent competition with different nutrients or to avoid pathogens. Furthermore, the utilization rates of all carboxylic acids were found to be highest in the samples collected under the canopy of $H$. subaxillaris and lowest in the samples collected under the canopy of

A. monosperma in most samples. This is in contrast to our hypothesis, in which we assumed that substrate utilization would be lower in the soil surrounding the invasive species in comparison with the soil surrounding the native plants.

This finding is very interesting in light of the fact that Morimoto et al. (2009) found members of the carboxylic group within the glandular trichomes on the leaf surfaces of $H$. subaxillaris, which might have caused a change in the soil microbial community so that it could better utilize this carbonic group. Most of the carbon substrates were positively correlated with soil moisture, suggesting that the presence of higher soil moisture and lower salinity results in greater utilization of carbon substrates added to the organic matter and nutrient-poor soils. These results indicate structural and functional differences in the microbial community between the three habitats, although in 
most samples, there were no significant differences in the measured environmental parameters between them, thus demonstrating how the alien plant $H$. subaxillaris changes its natural environment.

The microbial functional diversity found under the canopy of the native A. monosperma was higher at the western site compared with that found under the canopy of the invasive plant as a result of long-term

eco-physiological adaptation of the native plant. The lower diversity found under the canopy of the invasive plant was similar to what was shown in other studies on soil biota in general (Reinhart \& Callaway, 2006), and a soil microbial community in particular (Kivlin \& Hawkes, 2011). Nonetheless, compared with the bare areas, functional diversity was significantly higher $(p<0.05)$ in the invasive-plant environment, which indicates that its presence provides better conditions for the microbial community.

The lower values of basal respiration, microbial biomass, and functional diversity under the canopy of the invasive plant may be attributed to its volatile chemical-compound secretions (Morimoto et al., 2009), which allowed it to successfully compete with native plants and colonize new areas (Ben-Shahar, 2010), as found with other plant species as well (Bennett et al., 2011). The presence of $H$. subaxillaris is beneficial to the microbial community in most parameters compared with the natural community and the bare areas of the sand dunes because it improves conditions in this harsh environment. The change in community might also affect $H$. subaxillaris growth, as shown in other studies in which invasive plants often benefit from positive plant-soil feedback (van der Putten et al., 2007a; Pendergast et al., 2013; Bardgett and van der Putten, 2014; Gundale et al., 2014). Moreover, invasive plants can also indirectly benefit from altered plant-soil feedback by disturbing the positive feedback effect of native plants (Suding et al. 2013). However, from a systemic point of view, this only benefits the microbial community on a short-term basis because, in the long term, there is evidence of the displacement of the native A. monosperma by the invasive plant (Dufour-Dror, 2012), a change that will cause a decrease in most parameters measured in this study compared with what would have been in these soils in their natural state.

Due to the complex interactions between plants and soil microbial communities (Bever, 2002; Klironomos, 2002; Yang et al., 2013), it becomes vital to consider the impact of plant invasion on these organisms at multiple trophic levels when managing invasive alien plants (Emery \& Doran, 2013). This is critical for the coastal sand dunes of Israel, a unique environment (Kutiel, 2001; Danin, 2005) that is vanishing before our eyes because of anthropogenic factors. Furthermore, the exclusion of $A$. monosperma by $H$. subaxillaris might be facilitated through the change in the soil microbial community, as was found in other species (Rudgers and Orr, 2009). This interaction should be investigated in order to manage this invasive plant.

\subsection{Conclusions}

This study illustrates the changes in basal respiration, microbial biomass, substrate utilization rates, and functional diversity in samples collected under the canopy of a native plant (A. monosperma), an invasive alien plant ( $H$. subaxillaris), and in bare areas - in a sand-dune ecosystem. Although these two species are allelopathic, we found that basal respiration, microbial biomass, and functional diversity were lower in the presence of the invasive species compared with the native one, but higher compared with the bare areas in most cases. This indicates that $H$. subaxillaris changes the natural environment of the invaded sand dunes. Further research on its influence on such a fragile ecosystem and better understanding of the interaction between invasive plants and soil biota are needed. Our results emphasize the significance of coastal sand-dune conservation and invasive-plant management, and might be an important indicator of the state of sand-dune areas.

\section{Acknowledgments}

We would like to thank Dr. Stanislav Pen-Mouratov for his assistance during the study period. We also thank Ms. Sharon Victor for her comments and for preparing the manuscript for publication. This research is part of the Ph.D. thesis of Haggai Wasserstrom. The authors did not receive funding for this research.

\section{References}

Agrawal, A. A., Kotanen, P. M., Mitchell, C. E., Power, A. G., Godsoe, W., \& Klironomos, J. (2005). Enemy release? An experiment with congeneric plant pairs and diverse above- and belowground enemies. Ecology, 86, 2979-2989.

Aguilera, L. E., Gutiérrez, J. R., \& Meserve, P. L. (1999). Variation in soil micro-organisms and nutrients underneath and outside the canopy of Adesmia bedwellii (Papilionceae) shrubs in arid coastal Chile following drought and above average rainfall. Journal of Arid Environments, 42, 61-70.

Al-Watban, A., \& Salama, H. M. H. (2012). Physiological effects of allelopathic activity of Artemisia monosperma on common bean (Phaseolus vulgaris L.). International Research Journal of Plant Science, 3, $158-163$. 
Anderson, J. P. E., \& Domsch, K. H. (1978). Physiological method for quantitative measurement of microbial biomass in soils. Soil Biology and Biochemistry, 10, 215-221.

Anderson, T. H. (2003). Microbial eco-physiological indicators to asses soil quality. Agriculture, Ecosystems \& Environment, 98, 285-293.

Awang, M. B., \& Monaco, T. J. (1978). Germination, growth, development, and control of camphorweed (Heterotheca subaxillaris). Weed Science, 26, 51-57.

Bais, H. P., Weir, T. L., Perry, L. G., Gilroy, S., \& Vivanco, J. M. (2006). The role of root exudates in rhizosphere interations with plants and other organisms. Annual Review of Plant Biology, 57, 233-266.

Bardgett, R. D., \& van der Putten, W. H. (2014). Belowground biodiversity and ecosystem functioning. Nature, 515, 505-511.

Baskin, J. M., \& Baskin, C. C. (1976). Germination dimorphism in Heterotheca subaxillaris var Subaxillaris. Bulletin of the Torrey Botanical Club, 103, 201-206. https://doi.org/10.2307/2484679.

Batten, K. M., Scow, K. M., \& Espeland, E. K. (2008). Soil microbial community associated with an invasive grass differentially impacts native plant performance. Microbial Ecology, 55, 220-228.

Belnap, J., Phillips, S. L., Sherrod, S. K., \& Moldenke, A. (2005). Soil biota can change after exotic plant invasion: does this affect ecosystem processes? Ecology, 86, 3007-3017.

Bennett, A. E., Thomsen, M., \& Strauss, S. Y. (2011). Multiple mechanisms enable invasive species to suppress native species. American Journal of Botany, 98, 1086-1094.

Ben-Shahar, S. (2010). Causes, processes and attributes which make a plant specie more invasive: the case of Heterotheca subaxillaris (Asteracea) in coastal sand of Israel (Unpublished Master's thesis). Ben-Gurion University of the Negev, Beer Sheva, Israel (in Hebrew, English Abstract).

Berg, G., \& Smalla, K. (2009). Plant species and soil type cooperatively shape the structure and function of microbial communities in the rhizosphere. FEMS Microbiology Ecology, 68, 1-13.

Berg, N., \& Steinberger, Y. (2008). Role of perennial plants in determining the activity of the microbial community in the Negev Desert ecosystem. Soil Biology and Biochemistry, 40, 2686-2695. https://doi.org/10.1016/j.soilbio.2008.07.019.

Bever, J.D. (2002). Negative feedback within a mutualism: host-specific growth of mycorrhizal fungi reduces plant benefit. Proceedings of the Royal Society of London B - Biological Sciences, 269, 2595-2601. https://doi.org/10.1098/rspb.2002.2162.

Breckle, S. W., Yair, A., \& Veste, M. (Eds.) (2008). Arid dune ecosystems: the Nizzana sands in the Negev Desert (Vol. 200). Springer Science and Business Media.

Callaway, R. M., \& Maron, J. L. (2006). What have exotic plant invasions taught us over the past 20 years? Trends in Ecology \& Evolution, 21, 369-374.

Callaway, R. M., Thelen, G. C., Rodriguez, A., \& Holben, W. E. (2004). Soil biota and exotic plant invasion. Nature, 427, 731-733.

Campbell, C. D., Chapman, S. J., Cameron, C. M., Davidson, M. S., \& Potts, J. M. (2003). A rapid microtiter plate method to measure carbon dioxide evolved from carbon substrate amendments so as to determine the physiological profiles of soil microbial communities by using whole soil. Applied and Environmental Microbiology, 69, 3593-3599.

Chen, B. M., Peng, S. L., \& Ni, G. Y. (2009). Effects of the invasive plant Mikania micrantha HBK on soil nitrogen availability through allelopathy in South China. Biological Invasions, 11, 1291-1299. https://doi.org/10.1007/s10530-008-9336-9

Cipollini, D., Rigsby, C. M., \& Barto, E. K. (2012). Microbes as targets and mediators of allelopathy in plants. Journal of Chemical Ecology, 38, 714-727.

Coleman, M. D., Dickson, R. E., \& Isebrands, J. G. (2000). Contrasting fine-root production, survival and soil $\mathrm{CO}_{2}$ efflux in pine and poplar plantations. Plant and Soil, 225, 129-139.

Creamer, R. E., Stone, D., Berry, P., \& Kuiper, I. (2016). Measuring respiration profiles of soil microbial communities across Europe using MicroResp ${ }^{\mathrm{TM}}$ method. Applied Soil Ecology, 97, 36-43. 
Cronk, Q. C. B., \& Fuller, J. L. (2001). Plant invaders: The threat to natural ecosystems. Sterling, VA: Earthscan Publications, Ltd.

Dafni, A., \& Heller, D. (1980). The threat posed by alien weeds in Israel. Weed Research, 20, 277-283.

Danin, A. (2005). The sandy areas of Caesarea, a rare situation of alpha and beta diversity linked by plant succession. Israel Journal of Plant Sciences, 53, 247-252.

Danin, A., \& Yaalon, D. H. (1982). Silt plus clay sedimentation and decalcification during plant succession in sands of the Mediterranean coastal plain of Israel. Israel Journal of Earth Sciences, 31, 101-109.

Day, N. J., Antunes, P. M., \& Dunfield, K. E. (2015). Changes in arbuscular mycorrhizal fungal communities during invasion by an exotic invasive plant. Acta Oecologica, 67, 66-74.

De Deyn, G. B., Raaijmakers, C. E., Zoomer, H. R., Berg, M. P., de Ruiter, P. C., Verhoef, H. A., Bezemer, T. M., $\&$ van der Putten, W. H. (2003). Soil invertebrate fauna enhances grassland succession and diversity. Nature, 422, 711-713. https://doi.org/10.1038/Nature01548.

De Rooij-van der Goes, P. C. E. M., Van Dijk, C., van der Putten, W. H., \& Jungerius, P. D. (1997). Effects of sand movement by wind on nematodes and soil-borne fungi in coastal foredunes. Journal of Coastal Conservation, 3, 133-142.

Dufour-Dror, J. -M. (2012). Alien invasive plants in Israel. Jerusalem: The Middle East Nature Conservation Promotion Association.

Ehrenfeld, J. G. (2003). Effects of exotic plant invasions on soil nutrient cycling processes. Ecosystems, 6, 503-523.

Ehrlich, R., Schulz, S., Schloter, M., \& Steinberger, Y. (2015). Effect of slope orientation on microbial community composition in different particle size fractions from soils obtained from desert ecosystems. Biology and Fertility of Soils, 51, 507-510.

Emery, S. M., \& Doran, P. J. (2013). Presence and management of the invasive plant Gypsophila paniculata (baby's breath) on sand dunes alters arthropod abundance and community structure. Biological Conservation, 161, 174-181.

Engelkes, T., Morrien, E., Verhoeven, K. J. F., Bezemer, T. M., Biere, A., Harvey, J. A., McIntyre, L. M., Tamis, W. L. M., \& van der Putten, W. H. (2008). Successful range-expanding plants experience less above-ground and below-ground enemy impact. Nature, 456, 946-948.

Fitoussi, N., Pen-Mouratov, S., \& Steinberger, Y. (2016). Soil free-living nematodes as bio-indicators for assaying the invasive effect of the alien plant Heterotheca subaxillaris in a coastal dune ecosystem. Applied Soil Ecology, 102, 1-9.

Forster, S. M., \& Nicolson, T. H. (1981). Aggregation of sand from a maritime embryo sand dune by microorganisms and higher plants. Soil Biology and Biochemistry, 13, 199-203. https://doi.org/10.1016/ 0038-0717(81)90020-1.

Foster, B. L., \& Tilman, D. (2000). Dynamic and static views of succession: Testing the descriptive power of the chronosequence approach. Plant Ecology, 146, 1-10. https://doi.org/10.1023/A:1009895103017.

Foxcroft, L. C., Pyšek, P., Richardson, D. M., \& Genovesi, P. (2013). Plant invasions in protected areas. Dordrecht: Springer.

Gillespie, I. G., \& Allen, E. B. (2006). Effects of soil and mycorrhizae from native and invaded vegetation on a rare California forb. Applied Soil Ecology, 32, 6-12.

Goldsmith, V., Rosen, P., \& Gertner, Y. (1990). Eolian transport measurements, winds, and comparison with theoretical transport in Israeli coastal dunes. In K. F. Nordstrom, N. P. Psuty, \& R. W. G. Carter (Eds.), Coastal dunes: Form and process (pp. 79-101). Brisbane: John Wiley and Sons.

Grayston, S. J., Griffith, G. S., Mawdsley, J. L., Campbell, C. D., \& Bardgett, R. D. (2001). Accounting for variability in soil microbial communities of temperate upland grassland ecosystems. Soil Biology and Biochemistry, 33, 533-551.

Gundale, M. J., Kardol, P., Nilsson, M. C., Nilsson, U., Lucas, R. W., \& Wardle, D. A. (2014). Interactions with soil biota shift from negative to positive when a tree species is moved outside its native range. New Phytologist, 202, 415-421.

Hicks, S. L. (2004). The effects of invasive species on soil biogeochemistry. Amherst, MA: Hampshire College. 
Hill, S. J., Tung, P. J., \& Leischman, M. R. (2005). Relationships between anthropogenic disturbance, soil properties and plant invasion in endangered Cumberland Plain Woodland, Australia. Australian Ecology, 30, 775-788.

Inderjit, \& van der Putten, W. H. (2010). Impacts of soil microbial communities on exotic plant invasions. Trends in Ecology and Evolution, 25, 512-519. DOI 10.1016/j.tree.2010.06.006.

Jones, M. L. M., Sowerby, A., Williams, D. L., \& Jones, R. E. (2008). Factors controlling soil development in sand dunes: evidence from a coastal dune soil chronosequence. Plant and Soil, 307, 219-234. https://doi.org/10.1007/s11104-008-9601-9.

Kardol, P., Cornips, N. J., van Kempen, M. M., Bakx-Schotman, J. T., \& van der Putten, W. H. (2007). Microbe-mediated plant-soil feedback causes historical contingency effects in plant community assembly. Ecological Monographs, 77, 147-162.

Kardol, P., De Deyn, G. B., Laliberte, E., Mariotte, P., \& Hawkes, C. V. (2013). Biotic plant-soil feedbacks across temporal scales. Journal of Ecology, 101, 309-315. https://doi.org/10.1111/1365-2745.12046.

Kivlin, S. N., \& Hawkes, C. V. (2011). Differentiating between effects of invasion and diversity: impacts of aboveground plant communities on belowground fungal communities. New Phytologist, 189, 526-535. https://doi.org/10.1111/j.1469-8137.2010.03494.x.

Klironomos, J. N. (2002). Feedback with soil biota contributes to plant rarity and invasiveness in communities. Nature, 417, 67-70. https://doi.org/10.1038/417067a.

Kong, C. H., Wang, P., Zhao, H., Xu, X. H., \& Zhu, Y. D. (2008). Impact of allelochemical exuded from allelopathic rice on soil microbial community. Soil Biology and Biochemistry, 40, 1862-1869.

Kourtev, P. S., Ehrenfeld, J. G., \& Häggblom, M. (2002). Exotic plant species alter the microbial community structure and function in the soil. Ecology, 83, 3152-3166.

Kulmatiski, A., Beard, K. H., Stevens. J. R., \& Cobbold, S. M. (2008). Plant-soil feedbacks: a meta-analytical review. Ecological Letters, 11, 980-992.

Kutiel, P. (2001). Conservation and management of the Mediterranean coastal sand dunes in Israel. Journal of Coastal Conservation, 7, 183-192.

Kutiel, P. B., Katz, O., Ziso-Cohen, V., Divinsky, I., \& Katra, I. (2016). Water availability in sand dunes and its implications for the distribution of Artemisia monosperma. Catena, 137, 144-151.

Levin, N., Kidron, G. J., \& Ben-Dor, E. (2008). A field quantification of coastal dune perennial plants as indicators of surface stability, erosion or deposition. Sedimentology, 55, 751-772.

Levine, J. M., Vila, M., D'Antonio, C. M., Dukes, J. S., Grigulis, K., \& Lavorel, S. (2003). Mechanisms underlying the impacts of exotic plant invasions. Proceedings of the Royal Society of London B - Biological Sciences, 270, 775-781. https://doi.org/10.1098/rspb.2003.2327.

Liao, C. Z., Peng, R. H., Luo, Y. Q., Zhou, X. H., Wu, X. W., Fang, C. M., Chen, J. K., \& Li, B. (2008). Altered ecosystem carbon and nitrogen cycles by plant invasion: a meta-analysis. New Phytologist, 177, $706-714$.

Lonard, R. I., Judd, F. W., \& Stalter, R. (2011). Biological flora of coastal dunes and wetlands: Heterotheca subaxillaris (J. de Lamarck) N. Britton \& H. Rusby. Journal of Coastal Research, 27, 1052-1058. https://doi.org/10.2112/Jcoastres-D-11-00049.1.

Maron, J. L., Klironomos, J., Waller, L., \& Callaway, R. M. (2014). Invasive plants escape from suppressive soil biota at regional scales. Journal of Ecology, 102, 19-27.

Maun, M. A. (2009). The biology of coastal sand dunes. New York: Oxford University Press.

McLachlan, A., \& Brown, A. C. (2006). The ecology of sandy shores. Burlington, MA: Academic Press.

Meisner, A., Hol, W. G., de Boer, W., Krumins, J. A., Wardle, D. A., \& van der Putten, W. H. (2014). Plant-soil feedbacks of exotic plant species across life forms: a meta-analysis. Biological Invasions, 16, 2551-2561.

Morimoto, M., Cantrell, C. L., Libous-Bailey, L., \& Duke, S. O. (2009). Phytotoxicity of constituents of glandular trichomes and the leaf surface of camphorweed, Heterotheca subaxillaris. Phytochemistry, 70, 69-74. https://doi.org/10.1016/j.phytochem.2008.09.026 
Morriën, E., Duyts, H., \& van der Putten, W. H. (2012). Effects of native and exotic range-expanding plant species on taxonomic and functional composition of nematodes in the soil food web. Oikos, 121, 181-190. https://doi.org/10.1111/j.1600-0706.2011.19773.x.

Mummey, D. L., \& Rillig, M. C. (2006). The invasive plant species Centaurea maculosa alters arbuscular mycorrhizal fungal communities in the field. Plant and Soil, 288, 81-90.

Nicolson, T. H. (1960). Mycorrhiza in the Gramineae. II. Development in different habitats, particularly sand dunes. Transactions of the British Mycological Society, 43, 132-145.

Niro, E., Marzaioli, R., De Crescenzo, S., D'Abrosca, B., Castaldi, S., Esposito, A., \& Rutigliano, F. A. (2016). Effects of the allelochemical coumarin on plants and soil microbial community. Soil Biology and Biochemistry, 95, 30-39.

Paradelo, R., \& Barral, M. T. (2009). Effect of moisture and disaggregation on the microbial activity of soil. Soil Tillage Research, 104, 317-319. https://doi.org/10.1016/j.still.2009.02.010.

Pendergast, T. H., Burke, D. J., \& Carson, W. P. (2013). Belowground biotic complexity drives aboveground dynamics: a test of the soil community feedback model. New Phytologist, 197, 1300-1310.

Philippot, L., Raaijmakers, J. M., Lemanceau, P., \& van der Putten, W. H. (2013). Going back to the roots: the microbial ecology of the rhizosphere. Nature Reviews Microbiology, 11, 789-799.

Piśkiewicz, A. M., Duyts, H., Berg, M. P., Costa, S. R., \& van der Putten, W. H. (2007). Soil microorganisms control plant ectoparasitic nematodes in natural coastal foredunes. Oecologia, 152, 505-514.

Pringle, A., Bever, J. D., Gardes, M., Parrent, J. L., Rillig, M. C., \& Klironomos, J. N. (2009). Mycorrhizal symbioses and plant invasions. Annual Review of Ecology, Evolution, and Systematics, 40, 699-715.

Reinhart, K. O., \& Callaway, R. M. (2006). Soil biota and invasive plants. New Phytologist, 170, 445-457. https://doi.org/10.1111/j.1469-8137.2006.01715.x.

Rodríguez-Echeverría, S., de la Peña, E., Moens, M., Freitas, H., \& van der Putten, W. H. (2009). Can root-feeders alter the composition of AMF communities? Experimental evidence from the dune grass Ammophila arenaria. Basic and Applied Ecology, 10, 131-140.

Rowell, D. L. (1994). Soil science: Methods and applications. London: Longman Group UK Ltd.

Rudgers, J. A., \& Orr, S. (2009). Non-native grass alters growth of native tree species via leaf and soil microbes. Journal of Ecology, 97, 247-255.

Schloter, M., Dilly, O., \& Munch, J. C. (2003). Indicators for evaluating soil quality. Agriculture, Ecosystems \& Environment, 98, 255-262.

Sikes, B. A., Maherali, H., \& Klironomos, J. N. (2012). Arbuscular mycorrhizal fungal communities change among three stages of primary sand dune succession but do not alter plant growth. Oikos, 121, 1791-1800.

Souza-Alonso, P., Guisande-Collazo, A., \& González, L. (2015). Gradualism in Acacia dealbata Link invasion: Impact on soil chemistry and microbial community over a chronological sequence. Soil Biology and Biochemistry, 80, 315-323.

Suding, K. N., Stanley Harpole, W., Fukami, T., Kulmatiski, A., MacDougall, A. S., Stein, C., \& van der Putten, W. H. (2013). Consequences of plant-soil feedbacks in invasion. Journal of Ecology, 101, 298-308.

ter Braak, C. J. F. (1995). Ordination (Chapter 5). In R. H. G. Jongman, C. J. F. ter Braak, \& O. F. R. Van Tongeren (Eds.), Data analysis in community and landscape ecology (pp. 91-173). Cambridge, UK: Cambridge University Press.

Traveset, A., \& Richardson, D. M. (2006). Biological invasions as disruptors of plant reproductive mutualisms. Trends in Ecology and Evolution, 21, 208-216.

Vandenkoornhuyse, P., Bauldauf, S., Leyval, C., Straczek, J., \& Young, W. P. J. (2002). Extensive fungal diversity in plant roots. Science, 295, 2051.

van der Putten, W. H. (2009). A multitrophic perspective on functioning and evolution of facilitation in plant communities. Journal of Ecology, 97, 1131-1138.

van der Putten, W. H., Klironomos, J. N., \& Wardle, D. A. (2007a). Microbial ecology of biological invasions. ISME Journal, 1, 28-37. 
van der Putten, W. H., Kowalchuk, G. A., Brinkman, E. P., Doodeman, G. T. A., van der Kaaij, R. M., Kamp, A. F. D., \& Veenendaal, E. M. (2007b.) Soil feedback of exotic savanna grass relates to pathogen absence and mycorrhizal selectivity. Ecology, 88, 978-988.

van der Stoel, C. D., van der Putten, W. H., \& Duyts, H. (2002). Development of a negative plant-soil feedback in the expansion zone of the clonal grass Ammophila arenaria following root formation and nematode colonization. Journal of Ecology, 90, 978-988.

Vilà, M., Espinar, J. L., Hejda, M., Hulme, P. E., Jarošík, V., Maron, J. L., Pergl, J., Schaffner, U., Sun, Y., \& Pyšek, P. (2011). Ecological impacts of invasive alien plants: a meta-analysis of their effects on species, communities and ecosystems. Ecology Letters, 14, 702-708.

Vivanco, J. M., Bais, H. P., Stermitz, F. R., Thelen, G. C., \& Callaway, R. M. (2004). Biogeographical variation in community response to root allelochemistry: novel weapons and exotic invasion. Ecology Letters, 7, 285-292.

Wagg, C., Bender, S. F., Widmer, F., \& van der Heijden, M. G. (2014). Soil biodiversity and soil community composition determine ecosystem multifunctionality. Proceedings of the National Academy of Sciences of the United States of America, 111, 5266-5270.

Wardle, D. A., Bardgett, R. D., Klironomos, J. N., Setala, H., van der Putten, W. H., \& Wall, D. H. (2004). Ecological linkages between aboveground and belowground biota. Science, 304, 1629-1633.

Wasserstrom, H., \& Steinberger, Y. (2016). Does distance from the sea affect a soil microarthropod community? Acta Oecologica, 76, 39-46.

Wasserstrom, H., Whitford, W. G., \& Steinberger, Y. (2016). Spatiotemporal variations of soil microarthropod communities in the Negev Desert. Pedosphere, 26, 451-461.

Weidenhamer, J. D., \& Callaway, R. M. (2010). Direct and indirect effects of invasive plants on soil chemistry and ecosystem function. Journal of Chemical Ecology, 36, 59-69.

Williams, P. A., \& Karl, B. J. (2002). Birds and small mammals in kanuka (Kunzea ericoides) and gorse (Ulex europaeus) scrub and the resulting seed rain and seedling dynamics. New Zealand Journal of Ecology, 26, $31-41$.

Wolfe, B. E., \& Klironomos, J. N. (2005). Breaking new ground: Soil communities and exotic plant invasion. Bioscience, 55, 477-487. https://doi.org/10.1641/0006-3568(2005)055[0477:Bngsca]2.0.Co;2.

Yang, Q., Carrillo, J., Jin, H. Y., Shang, L., Hovick, S. M., Nijjer, S., Gabler, C. A., Li, B., \& Siemann, E. (2013). Plant-soil biota interactions of an invasive species in. its native and introduced ranges: Implications for invasion success. Soil Biology and Biochemistry, 65, 78-85.

Zak, J. C., Willig, M. R., Moorhead, D. L., \& Wildman, H. G. (1994). Functional diversity of microbial communities: a quantitative approach. Soil Biology and Biochemistry, 26, 1101-1108.

Zhou, B., Kong, C. H., Li, Y. H., Wang, P., \& Xu, X. H. (2013). Crabgrass (Digitaria sanguinalis) allelochemicals that interfere with crop growth and the soil microbial community. Journal of Agricultural and Food Chemistry, 61, 5310-5317.

\section{Copyrights}

Copyright for this article is retained by the author(s), with first publication rights granted to the journal.

This is an open-access article distributed under the terms and conditions of the Creative Commons Attribution license (http://creativecommons.org/licenses/by/4.0/). 